\title{
Effect of probiotic supplementation on growth performance, feed efficiency and carcass quality of broilers
}

\author{
S. B. ADANGALE, D. A.YADAV, T. R. WALKUNDE AND R. G. MALI
}

\begin{abstract}
An experiment was conducted and evaluated the influence of probiotic supplementation on growth, feed efficiency and carcass quality of broilers. The probiotic having different strains of beneficial micro-organisms viz., Lactobacillus acidophilus, Lactobacillus plantarum, Lactobacillus bulgaricus, Pediococcus acidilactici, Lactobacillus casei, Streptococcus thermophilus, Streptococcus faecium, Bifidobacterium bifidum was used for the study. Eighty day old (vencobb-400) chicks were distributed into four treatment groups $\mathrm{T}_{0}, \mathrm{~T}_{1}, \mathrm{~T}_{2}$ and $\mathrm{T}_{3}$ having 20 chicks in each group. The dietary treatments were planned as a control i.e. without probiotic $\left(\mathrm{T}_{0}\right)$, with probiotic powder @ $0.25 \mathrm{~g} / \mathrm{lit} .\left(\mathrm{T}_{1}\right), 0.50 \mathrm{~g} / \mathrm{lit} .\left(\mathrm{T}_{2}\right), 0.75 \mathrm{~g} / \mathrm{lit} .\left(\mathrm{T}_{3}\right)$, respectively. The gain in body weight and feed conversion of probiotic fed groups were superior $(\mathrm{p}<0.05)$ compared to the control group in the $4^{\text {th }}, 5^{\text {th }}$ and $6^{\text {th }}$ weeks. The highest feed consumption was noticed in $\mathrm{T}_{0}$ treatment. Statistically the difference in proximate composition of meat was nonsignificant which indicated that though the multistrain probiotic powder improved FCR but it does not affect the meat quality. It is, therefore, concluded that supplementation of multistrain probiotic powder through drinking water at the rate $0.50 \mathrm{~g} / \mathrm{lit}$. might be beneficial for broilers.
\end{abstract}

KEY WORDS : Probiotic, Broilers, Growth, Carcass

How TO CITE THIS PAPER : Adangale, S.B., Yadav, D.A., Walkunde, T.R. and Mali, R.G. (2017). Effect of probiotic supplementation on growth performance, feed efficiency and carcass quality of broilers. Res. J. Animal Hus. \& Dairy Sci., 8(2) : 85-89 : DOI: 10.15740/HAS/ RJAHDS/8.2/85-89.

Address for correspondence :

S.B. Adangale, Department of Animal Husbandry and Dairy Science, Mahatma Phule Krushi Vidyapeeth, Rahuri, AHMEDNAGAR (M.S.) INDIA

Email : drsunilmpkv@gmail.com

Associated Authors' :

D.A.Yadav, T.R. Walkunde and R.G. Mali, Department of Animal Husbandry and Dairy Science, Mahatma Phule Krushi Vidyapeeth, Rahuri, AHMEDNAGAR (M.S.) INDIA 